\title{
TU/e EmonOWEN

\section{Triple-Shape-Memory Soft Actuators from an Interpenetrating Network of Hybrid Liquid Crystals}

\section{Citation for published version (APA):}

Hoekstra, D. C., Debije, M. G., \& Schenning, A. P. H. J. (2021). Triple-Shape-Memory Soft Actuators from an Interpenetrating Network of Hybrid Liquid Crystals. Macromolecules, 54(12), 5410-5416.

https://doi.org/10.1021/acs.macromol.1c00611

DOI:

10.1021/acs.macromol.1c00611

Document status and date:

Published: 22/06/2021

\section{Document Version:}

Publisher's PDF, also known as Version of Record (includes final page, issue and volume numbers)

\section{Please check the document version of this publication:}

- A submitted manuscript is the version of the article upon submission and before peer-review. There can be important differences between the submitted version and the official published version of record. People interested in the research are advised to contact the author for the final version of the publication, or visit the $\mathrm{DOI}$ to the publisher's website.

- The final author version and the galley proof are versions of the publication after peer review.

- The final published version features the final layout of the paper including the volume, issue and page numbers.

Link to publication

\section{General rights}

Copyright and moral rights for the publications made accessible in the public portal are retained by the authors and/or other copyright owners and it is a condition of accessing publications that users recognise and abide by the legal requirements associated with these rights.

- Users may download and print one copy of any publication from the public portal for the purpose of private study or research.

- You may not further distribute the material or use it for any profit-making activity or commercial gain

- You may freely distribute the URL identifying the publication in the public portal.

If the publication is distributed under the terms of Article 25fa of the Dutch Copyright Act, indicated by the "Taverne" license above, please follow below link for the End User Agreement:

www.tue.nl/taverne

Take down policy

If you believe that this document breaches copyright please contact us at:

openaccess@tue.nl

providing details and we will investigate your claim. 


\title{
Triple-Shape-Memory Soft Actuators from an Interpenetrating Network of Hybrid Liquid Crystals
}

\author{
Davey C. Hoekstra, Michael G. Debije, and Albert P. H. J. Schenning* \\ Cite This: Macromolecules 2021, 54, 5410-5416 \\ Read Online
}

ABSTRACT: In this work, the formation of triple-shape-memory liquid crystalline-interpenetrating polymer network (LC-IPN) actuators based on a hybrid acrylate-oxetane LC mixture is reported. Orthogonal polymerization of the oxetane and acrylate liquid crystals creates polymer films with two distinct glasstransition temperatures. The use of these two transitions for oneway triple-shape-memory actuation and two-way bending actuation with a broad temperature window for actuation is demonstrated. Our results combine shape memory polymers with liquid crystalbased soft actuators having advanced stimuli-responsive properties.
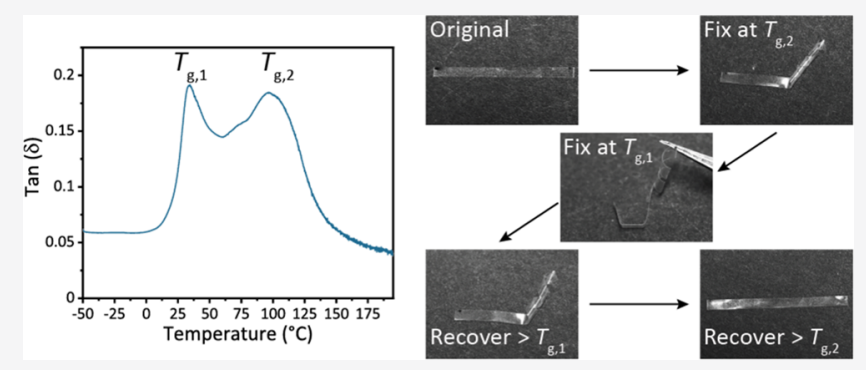

\section{INTRODUCTION}

Liquid crystalline (LC) polymer networks are an appealing class of materials for the fabrication of two-way soft actuators. $^{1-7}$ Their ease of fabrication combined with a large variety in LC phases and orientations have made them suitable for use in applications such as soft robotics ${ }^{8}$ and smart surfaces. ${ }^{9}$ LC-based actuators have been developed using a variety of polymerization methods and polymers. ${ }^{10-14}$ Moreover, soft actuators have also been combined with shape memory actuation for temporary three-dimensional (3D) shaping. ${ }^{15-20}$ All of these actuators are based on a single polymer network.

Interpenetrating polymer networks (IPNs) are systems consisting of "two cross-linked polymer networks that are physically entangled but not chemically linked”. ${ }^{21}$ IPNs have been drawing increasing attention in polymer science, as they often provide enhanced functional properties that are inaccessible using the individual polymers. ${ }^{22}$ In the field of LC polymers, several methods to fabricate liquid crystallineinterpenetrating networks (LC-IPNs) have been reported. ${ }^{23-32}$ Most of these LC-IPNs are based on interweaving acrylatebased liquid crystal networks (LCNs) with non-LC acrylate polymers $^{25-27}$ or with poly(dimethylsiloxane). ${ }^{28-31}$ These materials are, in fact, semi-IPNs, as the second component is a linear, non-cross-linked polymer. They are usually prepared in a two-step process wherein the LCN is synthesized first and subsequently swollen with the second monomer that is then also polymerized. Recently, a true LC-IPN based on a mainchain polyurethane liquid crystal elastomer (LCE) and a sidechain polyacrylate network has been developed. ${ }^{33}$ This material could be used as a temperature-responsive soft actuator having ultrastrong mechanical properties. To date, two-way soft actuators based on liquid crystal IPNs have not been applied as one-way shape memory actuators.
Recently, we reported on the wavelength-selective photopolymerization of a hybrid acrylate-oxetane cholesteric liquid crystal monomer mixture in which there was no difference in cross-link density between the acrylate and oxetane LC networks. ${ }^{34}$ In this work, the fabrication of an LC-IPN based on acrylate and oxetane LC monomers for use as shape memory materials and soft actuators is reported. The LC-IPN can be prepared in a one-pot fashion using common LCN production methods. By generating a large difference in the cross-link density between the acrylate and oxetane LC networks, two distinct glass transitions were obtained in the resulting LC-IPN. These separate glass transitions were used to obtain one-way triple-shape-memory actuation. ${ }^{35,36}$ Furthermore, the two-way bending actuation of splay-oriented LCIPNs was studied. The presence of two glass transitions results in a significantly broader temperature range in which actuation occurs.

\section{EXPERIMENTAL SECTION}

Materials. Liquid crystalline di-acrylate 2-methyl-1,4-phenylene bis(4-(((4-(acryloyloxy)butoxy)carbonyl)oxy)benzoate) (1) was purchased from BASF. Liquid crystalline di-oxetane 2-methyl-1,4phenylene bis(4-(4-((3-methyloxetan-3-yl)methoxy)butoxy)benzoate) (2) and liquid crystalline mono-oxetane 4-((4-(hexyloxy)benzoyl)oxy)-2-methylphenyl 4-(4-((3-methyloxetan-3-yl)methoxy)butoxy)benzoate (3) were obtained from Syncom B.V. according to previously reported procedures. ${ }^{37,38}$ The free-radical photoinitiator,

Received: March 18, 2021

Revised: May 22, 2021

Published: June 9, 2021 
Irgacure 819 (4), was purchased from BASF and the cationic photoinitiator, triarylsulfonium hexafluorophosphate salts in propylene carbonate (5), was purchased from Sigma-Aldrich.

LC-IPN Fabrication. Preparation of the LC Mixture. Liquid crystalline di-acrylate $1(50 \% \mathrm{w} / \mathrm{w})$, liquid crystalline di-oxetane 2 $(2.5 \% \mathrm{w} / \mathrm{w})$, and liquid crystalline mono-oxetane $3(47.5 \% \mathrm{w} / \mathrm{w})$ were combined in a glass vial and heated to melt the LC monomers. Subsequently, free-radical photoinitiator $4(1.0 \% \mathrm{w} / \mathrm{w})$ and cationic photoinitiator $5(2.5 \% \mathrm{w} / \mathrm{w})$ were added. To ensure proper mixing, the mixture was heated to its isotropic phase and stirred magnetically on a hot plate for $15 \mathrm{~min}$.

Fabrication of LC Alignment Cells. Overall, $3 \times 3 \mathrm{~cm}^{2}$ borosilicate glass slides were sonicated in acetone for $20 \mathrm{~min}$. They were then blown dry under $\mathrm{N}_{2}$ and placed in a UV/ozone oven (UV-Products PR-100) for $20 \mathrm{~min}$ to activate the surface. A polyimide (PI) precursor was spin-coated on the slides. Depending on the desired LC alignment, an Optmer AL1254 (JSR corp, spin-coated for $45 \mathrm{~s}$ at 1800 rpm) was used for planar alignment, or a Sunever 5661 (Nissan Chemical Corp, spin-coated $5 \mathrm{~s}$ at $800 \mathrm{rpm}$ followed by $45 \mathrm{~s}$ at 5000 $\mathrm{rpm}$ ) was used for homeotropic alignment. After spin-coating, the solvent was removed by heating the slides to $100{ }^{\circ} \mathrm{C}$ for $10 \mathrm{~min}$, and PI was then cured at $180{ }^{\circ} \mathrm{C}$ for $30 \mathrm{~min}$. The slides intended for planar alignment were rubbed on a velvet cloth to ensure uniaxial alignment. The alignment cells were made by gluing either two planar PI slides (in an antiparallel fashion) together with UV-curable glue for a planar cell or one planar PI slide and one homeotropic PI slide for splay alignment. The cell spacing was set using $30 \mu \mathrm{m}$ spacers in the glue.

Fabrication of the LC-IPN Films. The alignment cells were filled with the LC mixtures at $115{ }^{\circ} \mathrm{C}$ through capillary action. The cells were then slowly cooled such that the polymerization temperature was $T_{\text {pol }}=92{ }^{\circ} \mathrm{C}$ and left at that temperature for $15 \mathrm{~min}$ to ensure monodomain alignment. For simultaneous photopolymerization, the samples were then exposed to a flood UV exposure $\left(5 \mathrm{~mW} / \mathrm{cm}^{2}\right.$ UVA, Oriel Instruments) for $5 \mathrm{~min}$. For sequential photopolymerization, a $400 \mathrm{~nm}$ longpass filter (Thorlabs FGL400) was used in the first illumination step to exclusively activate the free-radical initiator for 5 min. A subsequent flood UV exposure for 5 min polymerized the oxetane LC monomers. A postcure of $30 \mathrm{~min}$ at $130{ }^{\circ} \mathrm{C}$ in an oven ensured maximum conversion and removed any polymerizationinduced stresses. The cells were then opened, and the freestanding films were removed from the glass substrates.

Characterization. Differential Scanning Calorimetry (DSC). DSC curves were measured with a DSC Q2000 from TA Instruments with heating and cooling rates of $10^{\circ} \mathrm{C} / \mathrm{min}$. Images of samples were taken with an Olympus OM-D E-M10III digital camera equipped with an Olympus MFT 60MM F/2.8 ED Macro M.Zuiko Digital lens. Polarized optical microscopy (POM) was performed on a Leica DM2700M equipped with crossed polarizers. The temperature was controlled by a Linkam PE95/T95 temperature controller. Scanning electron microscopy (SEM) was done using an FEI Quanta 3D SEM. The LCNs were first fractured in liquid $\mathrm{N}_{2}$, followed by Au sputtercoating treatment. Fourier-transform Infrared (FT-IR) analysis of monomer mixtures and freestanding films was performed on a Varian 670IR in an attenuated total reflection (ATR) mode. Dynamic mechanical analysis (DMA) was performed on a DMA850 Discovery from TA Instruments with tension clamps. Dynamic moduli and damping characteristics $(\tan \delta)$ were determined in an oscillatory mode (frequency: $1 \mathrm{~Hz}$, amplitude: $0.4 \%$ strain) on $7 \times 5.3 \mathrm{~mm}^{2}$ ribbons cut from the larger films. Thermally induced strain values were determined in a stress control mode, while exerting a small force $(0.005 \mathrm{~N})$ on the film, and reversible changes in the length were measured as a function of temperature. To remove any thermal history, two heating cycles are reported. For the triple-shape-memory cycles: (1) the sample was heated to $150{ }^{\circ} \mathrm{C}$ and equilibrated for 10 min and (2) uniaxial stretching was applied by a force ramp from 0.01 to $0.4 \mathrm{~N}$ at a rate of $0.5 \mathrm{~N} / \mathrm{min}$. (3) The strain was then fixed via cooling to $55{ }^{\circ} \mathrm{C}$ at a cooling rate of $5{ }^{\circ} \mathrm{C} / \mathrm{min}$, followed by equilibration for $30 \mathrm{~min}$. (4) The external force was then unloaded to $0.01 \mathrm{~N}$ at a rate of $0.5 \mathrm{~N} / \mathrm{min}$, followed by equilibration for $30 \mathrm{~min}$ to obtain S1. (5) Next, uniaxial stretching was applied by a force ramp from 0.01 to $1.4 \mathrm{~N}$ at a rate of $0.5 \mathrm{~N} / \mathrm{min}$. (6) The strain was then fixed via cooling to $0{ }^{\circ} \mathrm{C}$ at a cooling rate of $5{ }^{\circ} \mathrm{C} / \mathrm{min}$, followed by equilibration for $30 \mathrm{~min}$. (7) The external force was then unloaded to $0.01 \mathrm{~N}$ at a rate of $0.5 \mathrm{~N} / \mathrm{min}$, followed by equilibration for $30 \mathrm{~min}$ to obtain S2. (8) To recover from S2 to S1, the sample was heated to 55 ${ }^{\circ} \mathrm{C}$ to release that part of the strain followed by equilibration for $1 \mathrm{~h}$ to demonstrate sample stability. (9) To recover from S1 to S0, the sample was reheated to $150{ }^{\circ} \mathrm{C}$ to release the strain followed by equilibration for $1 \mathrm{~h}$. In the following three cycles, the procedure was repeated from step (2). The shape fixity $\left(R_{\mathrm{f}}\right)$ and shape recovery $\left(R_{\mathrm{r}}\right)$ rates were calculated using the equations

$$
\begin{aligned}
& R_{\mathrm{f}}(\mathrm{S} 1)=\frac{\varepsilon_{\mathrm{S} 1}-\varepsilon_{\mathrm{S} 0}}{\varepsilon_{\mathrm{S} 1, \text { load }}-\varepsilon_{\mathrm{S} 0}} \times 100 \% \\
& R_{\mathrm{f}}(\mathrm{S} 2)=\frac{\varepsilon_{\mathrm{S} 2}-\varepsilon_{\mathrm{S} 1}}{\varepsilon_{\mathrm{S} 2, \text { load }}-\varepsilon_{\mathrm{S} 1}} \times 100 \% \\
& R_{\mathrm{r}}(\mathrm{S} 2-\mathrm{S} 1)=\frac{\varepsilon_{\mathrm{S} 2}-\varepsilon_{\mathrm{S} 1 \text {,rec }}}{\varepsilon_{\mathrm{S} 2}-\varepsilon_{\mathrm{S} 1}} \times 100 \% \\
& R_{\mathrm{r}}(\mathrm{S} 1-\mathrm{S} 0)=\frac{\varepsilon_{\mathrm{S} 1}-\varepsilon_{\mathrm{S} 0, \mathrm{rec}}}{\varepsilon_{\mathrm{S} 1}-\varepsilon_{\mathrm{S} 0}} \times 100 \%
\end{aligned}
$$

where $\varepsilon_{\mathrm{S} 0}$ is the measured strain before the application of stress, $\varepsilon_{\mathrm{S} 1, \mathrm{load}}$ is the strain after applying the first stress, $\varepsilon_{S 1}$ is the strain after release of this applied stress, $\varepsilon_{\mathrm{S} 2 \text {,load }}$ is the strain applying the second stress, $\varepsilon_{\mathrm{S} 2}$ is the strain after the release of this stress, $\varepsilon_{\mathrm{S} 1 \text {,rec }}$ is the strain after the first recovery step, and $\varepsilon_{\mathrm{S} 0 \text {,rec }}$ is the strain after the final recovery step.

Analysis of Thermomechanical Actuation Behavior. Cut ribbons were placed in an oven with a window to allow recording of changes in the sample as the environment heats. The temperature was monitored using a digital sensor (Sensirion SHTC3). Images were taken with a digital camera (Olympus OM-D E-M10 Mk III) in a manual focus mode.

\section{RESULTS AND DISCUSSION}

An acrylate-oxetane liquid crystal mixture was developed with equal weight fractions of acrylate and oxetane LC monomers (Figure 1a). To obtain a large difference in the cross-link density between the individual networks in the LC-IPN, the acrylate fraction of the mixture consisted solely of LC diacrylate $\mathbf{1}$, whereas the oxetane fraction consisted of a small amount of di-oxetane $\mathbf{2}$ and a large portion of LC monooxetane 3. The oxetane LC fraction was chosen to be the loosely cross-linked network, as we have previously established that oxetane LCNs are softer than acrylate LCNs, ${ }^{18}$ maximizing the contrast in mechanical properties between the networks in the LC-IPN. Free-radical photoinitiator 4 and cationic photoinitiator $\mathbf{5}$ were added to the LC monomer mixture. The phase behavior of the resulting mixture was studied by differential scanning calorimetry (DSC), which showed an isotropic-to-nematic transition upon cooling at 111 ${ }^{\circ} \mathrm{C}$ (Figure S1). Upon further cooling, no additional phase transitions (e.g., crystallization) were observed. Further analysis by polarized optical microscopy (POM) showed a typical schlieren texture below $111{ }^{\circ} \mathrm{C}$, confirming the presence of a nematic LC phase, in analogy with the previously reported individual monomers (Figure S2). ${ }^{37,39}$

The acrylate-oxetane LC mixture was then used for the preparation of planar aligned LC-IPN films. Rubbed polyimide glass cells were filled with the mixture in its isotropic phase and subsequently cooled to the nematic phase at $92{ }^{\circ} \mathrm{C}$, such that $T_{\text {pol }}=0.95 \times T_{\mathrm{I}-\mathrm{N}}(\mathrm{K})$ (Figure $\left.1 \mathrm{~b}\right)$. The cell was then illuminated with UV light to activate both photoinitiators and initiate the polymerization of both the acrylate and the oxetane 


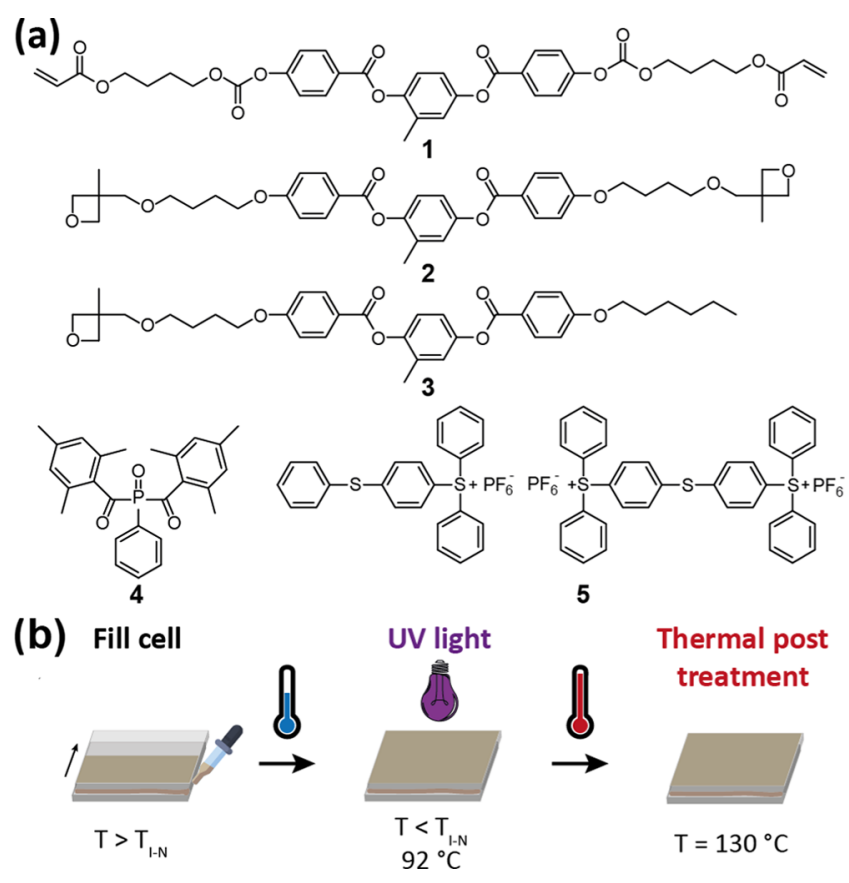

Figure 1. (a) Molecular structures of the acrylate LC monomer 1, the oxetane LC monomers 2 and 3, free-radical photoinitiator 4, and cationic photoinitiator 5 used in this work. (b) Procedure to fabricate LC-IPN films. An LC cell is filled with the acrylate-oxetane LC mixture in its isotropic phase. After complete filling, the cell is cooled to the nematic phase to align the monomers. UV light is used to activate the free-radical and cationic polymerization mechanisms. Subsequently, the cell is subjected to a thermal post treatment to ensure maximum conversion.
LC monomers to form the LC-IPN. Afterward, the cells were subjected to a thermal post treatment at $130{ }^{\circ} \mathrm{C}$ for $30 \mathrm{~min}$ to ensure maximum monomer conversion. Freestanding LC-IPN films were obtained after opening the cells. FT-IR analysis confirmed the conversion of both the acrylate and oxetane LC monomers, with the disappearance of the peaks corresponding to both the acrylate groups at 1410 and $811 \mathrm{~cm}^{-1}$ as well as the oxetane groups at $975 \mathrm{~cm}^{-1}$ (Figure 2a). The LC-IPN films were optically clear and easily bendable (Figure 2b), demonstrating that they are not brittle. Similar to the LC monomer mixture, the LC-IPN films were in the nematic phase. Due to the high degree of cross-linking, no transition to the isotropic phase upon heating was observed. Furthermore, by sequentially activating the photoinitiators, we were able to demonstrate the orthogonality of the free-radical and cationic polymerization reactions (Figure S3). ${ }^{34}$

Next, the thermomechanical behavior of the LC-IPN was studied by dynamic mechanical analysis (DMA). The storage and loss moduli of the homogeneously aligned film as a function of temperature were measured in the direction parallel to the nematic director, and are plotted in Figure 2c. At room temperature, the film is in a glassy state with a storage modulus, $E_{25}^{\prime}{ }^{\circ} \mathrm{C}=1.36 \mathrm{GPa}$. At this temperature, the film is already beginning a glass transition, which according to the onset in $E^{\prime}$ starts at $25.4^{\circ} \mathrm{C}$, and to the peak in $E^{\prime \prime}$ at $30.7{ }^{\circ} \mathrm{C}$. The peak in the damping curve $(\tan \delta)$ indicates this first glasstransition temperature $\left(T_{\mathrm{g}}\right)$ at $35{ }^{\circ} \mathrm{C}$. Based on the monomer composition, this glass transition can be ascribed to the oxetane LC network in the LC-IPN, as it has the lowest crosslink density. Further heating then induced a second glass transition in the acrylate LC network, with a second onset (a)

(b)
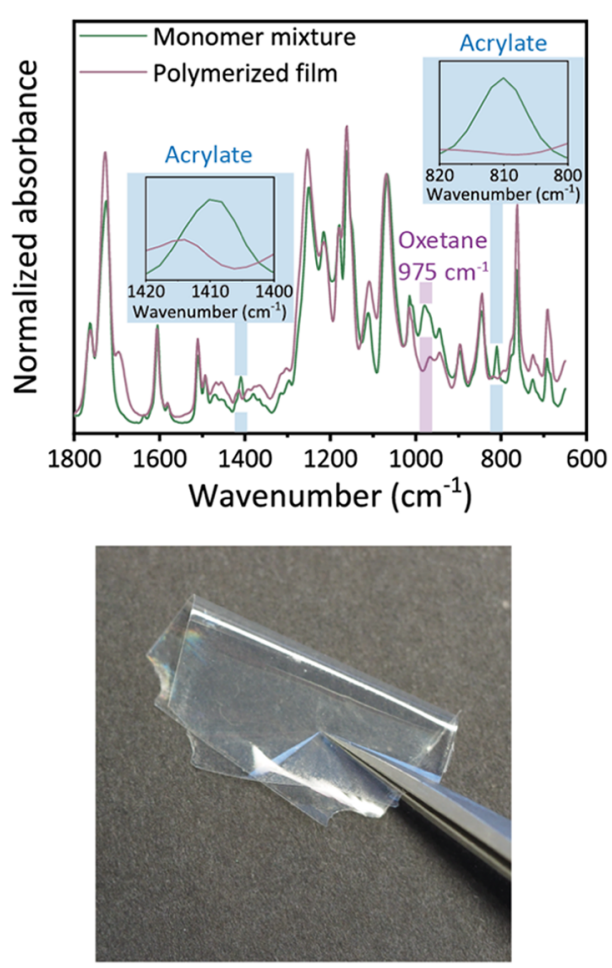

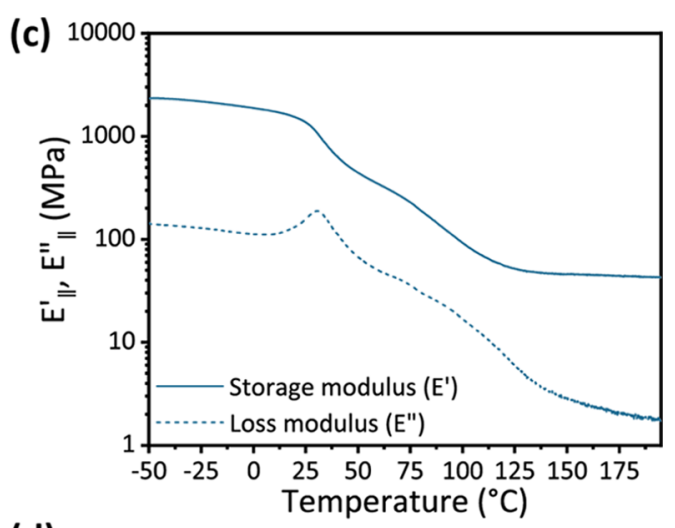

(d)

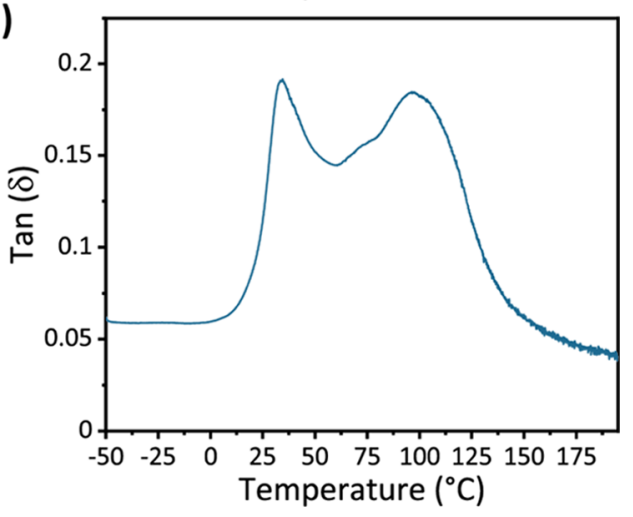

Figure 2. (a) FT-IR analysis of a photopolymerized LC-IPN film compared to its monomer mixture. (b) Image showing the optical clarity and flexibility of the LC-IPN film. (c) Thermomechanical properties of the LC-IPN film: storage $\left(E^{\prime}\right)$ and loss $\left(E^{\prime \prime}\right)$ moduli measured in the direction parallel to the LC orientation as a function of temperature. (d) Corresponding $\tan \delta$ curve. 
a) Dual-shape memory at $T_{\text {, } 1}$

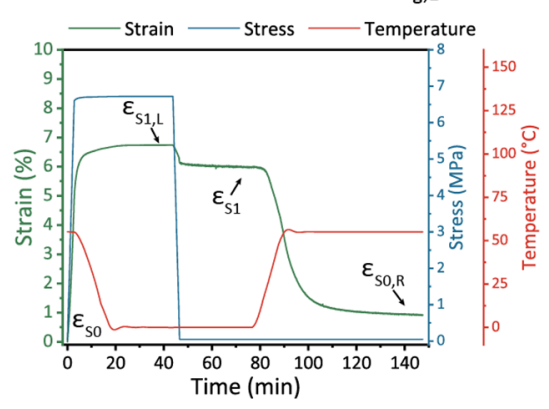

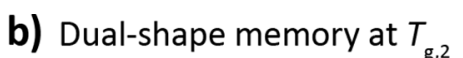

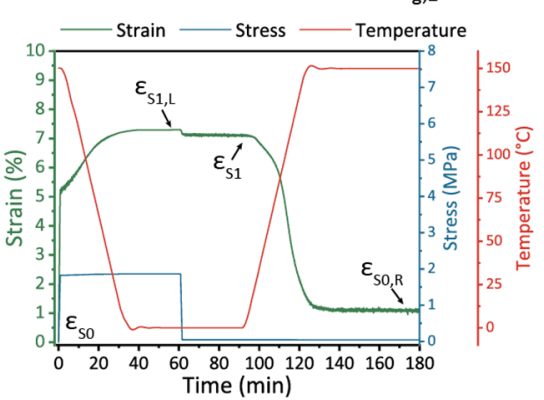

c) Triple-shape memory (1 cycle)

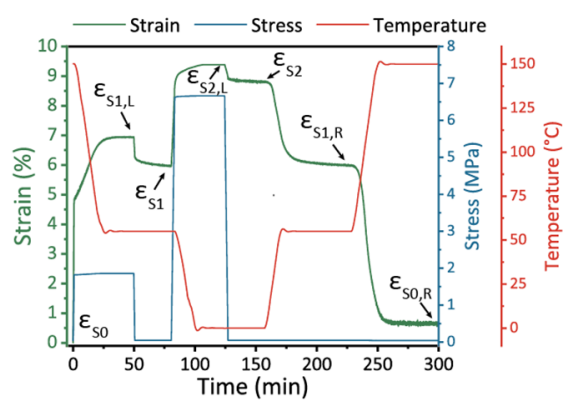

d)

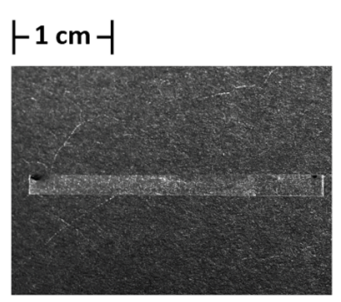

Shape A

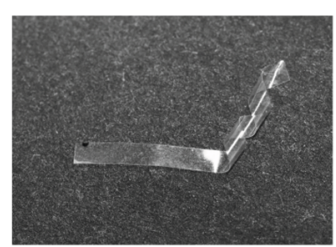

Shape B

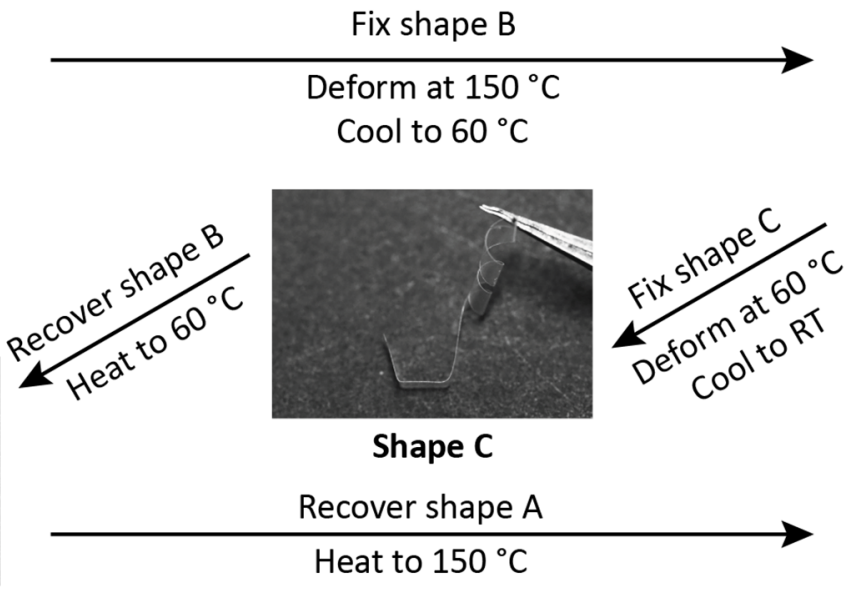

Heat to $150{ }^{\circ} \mathrm{C}$

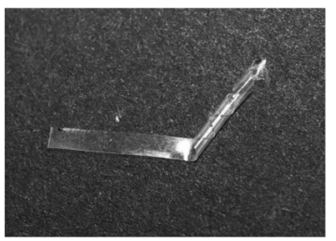

Shape B

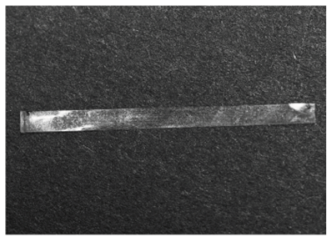

Shape A

Figure 3. (a) One-way dual-shape memory in the LC-IPN using the (a) glass transition in the oxetane network and the (b) glass transition in the acrylate network as switching elements. (c) One-way triple-shape memory in the LC-IPN, using both $T_{\mathrm{g}} \mathrm{s}$ as switching elements. (d) Demonstration of triple-shape memory in an LC-IPN strip (Shape A). An area of the strip was curled at $150{ }^{\circ} \mathrm{C}$ and then cooled to $60^{\circ} \mathrm{C}$, fixing the curl (shape B). The remaining area was then folded two times and cooled to RT (Shape C). Heating to $60{ }^{\circ} \mathrm{C}$ then led to the recovery of shape B, and further heating to $150^{\circ} \mathrm{C}$ led to the full recovery of shape A.

point in the storage modulus at $75{ }^{\circ} \mathrm{C}$ (Figure S4) and a peak in $\tan \delta$ at $96^{\circ} \mathrm{C}\left(T_{\mathrm{g}, 2}\right)$. Hence, two separate $T_{\mathrm{g}} \mathrm{s}$ are present in the LC-IPN film. These findings support the formation of an IPN film having two cross-linked polymer networks that are not chemically linked. Finally, we found that, similar to pure acrylate or oxetane $\mathrm{LCNs},{ }^{18,40}$ the homogeneously planar aligned LC-IPN has anisotropic thermomechanical properties (Figure S5).

One-Way Triple-Shape-Memory Actuation. The shape memory actuation behavior of the simultaneously polymerized LC-IPN was investigated quantitatively by DMA, in the direction parallel to the nematic director. The presence of two distinct glass transitions provides two switching elements that can be used to fix a temporary shape in the polymer film. Therefore, dual-shape memory was tested first at $55{ }^{\circ} \mathrm{C}$, which is in between the two glass transitions (Figure 3a). At this temperature, the oxetane LC network is in a rubber-like state, whereas the acrylate LC network is still in its glassy state. The application of relatively large stress of $6.7 \mathrm{MPa}$ induced a moderate strain of $5.7 \%$ that was fixed by cooling to $0{ }^{\circ} \mathrm{C}$. The strain increased during cooling, which is caused by the increased LC order. Subsequent removal of the stress led to a minor decrease in strain, with the shape fixity rate $R_{\mathrm{f}}=88.9 \%$. Heating to $130{ }^{\circ} \mathrm{C}$ then released the strain, with the shape recovery rate $R_{\mathrm{r}}=84.6 \%$. Next, the dual-shape-memory behavior was tested at $150{ }^{\circ} \mathrm{C}$, which is above the second glass transition (Figure $3 \mathrm{~b}$ ). At $150{ }^{\circ} \mathrm{C}$, both networks in the LCIPN are in a rubber-like state. As a result, the application of a stress of $1.84 \mathrm{MPa}$ led to a strain of initially $5.2 \%$. Hence, in the rubber-like state, a similar strain is achieved at significantly lower stress. In this state, the effect of LC order increase upon cooling is more pronounced, resulting in a strain of $7.3 \%$ after cooling to $0{ }^{\circ} \mathrm{C}$ to fix the strain. The shape fixity rate after removal of the stress was also higher than at $T_{\mathrm{g}, 1}, R_{\mathrm{f}}=97.5 \%$. Again, heating to $150{ }^{\circ} \mathrm{C}$ released the strain, recovering the original shape with a recovery rate $R_{\mathrm{r}}=84.8 \%$.

The presence of two switching possibilities, i.e., two $T_{\mathrm{g}} \mathrm{s}$, can also be used to fix two temporary shapes in the polymer film to create a triple-shape-memory actuator. This shape memory behavior was tested quantitatively by DMA (Figure 3c). First, the film was heated to $150{ }^{\circ} \mathrm{C}\left(T>T_{\mathrm{g}, 2}\right)$ and subjected to a stress of $1.85 \mathrm{MPa}$, straining the material to $5.0 \%$. It was then cooled to $60{ }^{\circ} \mathrm{C}\left(T_{\mathrm{g}, 1}<T<T_{\mathrm{g}, 2}\right)$ to fix the first temporary shape (S1), again straining the material further to $6.9 \%$ due to increased LC ordering. Removal of the stress led to a small decrease in strain to $6.0 \%$. Subsequently, the material was subjected to a larger stress of $6.65 \mathrm{MPa}$, increasing the strain to $9.0 \%$, which upon cooling to $0{ }^{\circ} \mathrm{C}\left(T<T_{\mathrm{g}, 1}\right)$ to fix the second temporary shape (S2) increased to $9.4 \%$. The stress was once more removed, resulting in a final strain of $8.8 \%$ in the programmed LC-IPN. Maintaining the material at $0{ }^{\circ} \mathrm{C}$ for $1 \mathrm{~h}$ showed that the programmed shape was stably held by the LC- 
Table 1. Shape Fixity $\left(R_{\mathrm{f}}\right)$ and Recovery Rates $\left(R_{\mathrm{r}}\right)$ Determined from Four Cycles of One-Way Triple-Shape-Memory Actuation in the LC-IPN

\begin{tabular}{llll} 
Cycle & \multicolumn{1}{c}{$R_{\mathrm{f}}(\mathrm{S} 1)$} & $R_{\mathrm{f}}(\mathrm{S} 2)$ & $R_{\mathrm{r}}(\mathrm{S} 2-\mathrm{S} 1)$ \\
1 & $86.0 \%$ & $83.3 \%$ & $99.3 \%$ \\
$2-4$ & $85.1 \% \pm 0.1 \%$ & $82.4 \% \pm 0.4 \%$ & $101.8 \% \pm 0.4 \%$ \\
\hline
\end{tabular}

(a)
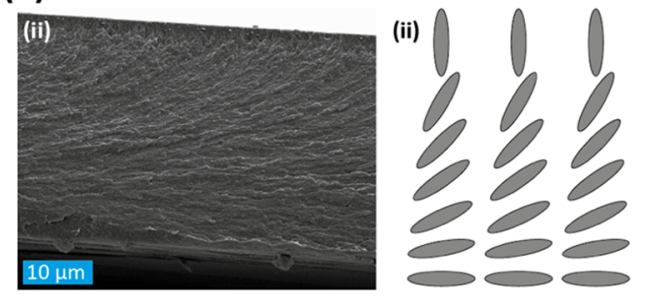

(b) $\vdash 2 \mathrm{~cm}-1$
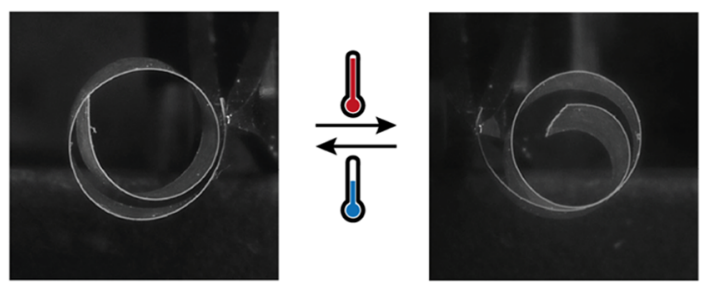

(c) $\vdash 2 \mathrm{~cm} \dashv$
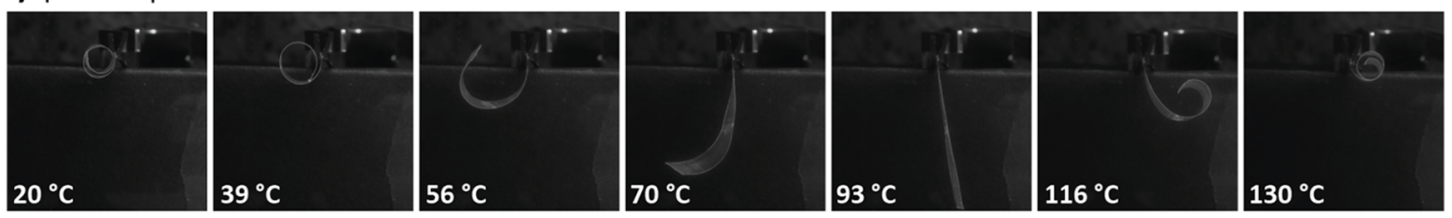

Heating
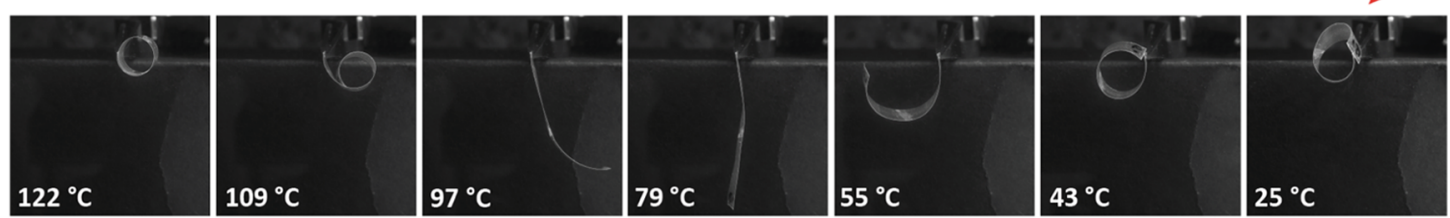

Cooling

Figure 4. Splay LC-IPN actuator. (a) SEM micrograph (i) and schematic representation (ii) showing the splay orientation through the film. (b) Actuation behavior of the film. Heating results in the material reverting from clockwise to anticlockwise rolling, whereas cooling leads to the opposite. (c) Detailed actuation behavior over a heating cycle, followed by a cooling cycle.

IPN. Next, the film was heated to $60{ }^{\circ} \mathrm{C}$ to recover from shape S2 to shape S1. Indeed, the strain decreased to $6.0 \%$. Importantly, when the material was kept at $60{ }^{\circ} \mathrm{C}$ for $1 \mathrm{~h}$, the strain did not decrease further, demonstrating the stability of the triple-shape-memory behavior. Further heating to 150 ${ }^{\circ} \mathrm{C}$ resulted in the recovery of most of the strain and the film returned to the initial shape S0. The triple-shape-memory actuation was repeated through four cycles (Figure S6), demonstrating reproducibility. An overview of the relevant shape fixity rates $\left(R_{\mathrm{f}}\right)$ and shape recovery rates $\left(R_{\mathrm{r}}\right)$ is given in Table 1. The LC-IPNs have good shape fixity and excellent shape recovery rates due to the LC order in the IPN providing the driving force for full shape recovery.

Finally, the one-way triple-shape-memory actuation was demonstrated qualitatively on a strip cut from the larger LCIPN parallel to the molecular director (Figure 3d, shape A) This strip was heated to $150{ }^{\circ} \mathrm{C}$, and a part of it was curled after which it was cooled to $60{ }^{\circ} \mathrm{C}$, fixing temporary shape $\mathrm{B}$. Next, the other part of the strip was bent in two locations and cooled to room temperature, fixing shape C. Subsequent heating to $60{ }^{\circ} \mathrm{C}$ led to the recovery of shape $\mathrm{B}$, with only minor uncurling. Finally, the film was heated to $150{ }^{\circ} \mathrm{C}$, which led to the full recovery of the original shape $\mathrm{A}$, with no obvious remaining kinks or bends.

Two-Way Bending Actuation. By aligning the LC monomer mixture in a splayed orientation, soft actuators can be obtained that display reversible two-way bending actuation. To obtain freestanding films, a splay LC cell was filled with the monomer mixture in the isotropic phase and subsequently cooled to its nematic phase $\left(92^{\circ} \mathrm{C}\right)$. The mixture was then photopolymerized by exposure to flood UV light for $5 \mathrm{~min}$, followed by a thermal post treatment at $130{ }^{\circ} \mathrm{C}$ for $30 \mathrm{~min}$. SEM analysis confirmed the splay orientation (Figure $4 \mathrm{a}$ ). Opening the cells led to freestanding films that curled at room temperature with the homeotropic side of the film inside the curvature, as a result of the increase in the LC order at room temperature compared to the higher polymerization temperature. In analogy with what was observed with pure oxetane LCN films, ${ }^{18}$ heating the film resulted in reversal of the curling direction from clockwise to anticlockwise (Figure 4b). A more detailed overview of the actuation behavior is given in Figure $4 c$. Upon heating, the films started unrolling. Due to the dual glass transitions in the film, the temperature window in which actuation occurs is wider than in a single-network LCN film. The gradual uncurling of the film already commenced at a slightly elevated temperature $\left(T<40{ }^{\circ} \mathrm{C}\right)$, after which it adopted a flat shape at $T=T_{\text {pol }}\left(92{ }^{\circ} \mathrm{C}\right)$ and then curled in the opposite direction. This curling is accelerated when the temperature exceeds $100{ }^{\circ} \mathrm{C}$, as the LC-IPN film is completely in a rubber-like state at this point. Subsequent cooling led to the complete reversal of the actuation. 
Commonly reported acrylate LCN splay actuators usually show a limited actuation behavior from a flat to a bent state. ${ }^{13}$ The oxetane LCN actuators we reported earlier were shown to display a significantly higher degree of actuation, most likely due to the higher flexibility of the polyether backbone. ${ }^{18}$ Here, the LC-IPN film consists of a strongly cross-linked acrylate LCN interwoven with a loosely cross-linked oxetane LCN. The combination of these networks in an IPN results in an actuator with good mechanical properties provided by the strong acrylate LC network, a high degree of actuation provided by the flexible oxetane LC network, and a wide temperature window for actuation due to the dual glass transitions induced by both networks.

\section{CONCLUSIONS}

A new class of LC-IPN actuators based on an acrylate-oxetane liquid crystal monomer mixture is reported. The initially wellmiscible monomers are ideal to serve as a one-pot system for the preparation of freestanding films of interpenetrating polymer networks with anisotropic thermal and mechanical properties. The orthogonality of the free-radical and cationic ring-opening polymerization mechanisms necessary to polymerize both monomer species allows for the fabrication of a true IPN with no chemical links between the networks.

The creation of a large difference in cross-link densities between the individual networks in the LC-IPN led to a polymer material with two separate $T_{\mathrm{g}} \mathrm{s}$, giving the LC-IPN additional benefits over single-network LCNs. The use of the LC-IPN as a one-way triple-shape-memory material was demonstrated. The two $T_{\mathrm{g}} \mathrm{s}$ facilitate the recording of two temporary shapes in the material, which was shown both qualitatively and quantitatively. Furthermore, when aligned in a splay orientation, the LC-IPN can be used as a two-way bending actuator that actuates over a broader temperature range compared to a single-network splay actuator.

These findings show that LC-IPNs based on LC monomers have potential as soft actuators having multiple temporary shapes. The combination of two LC networks into one polymer results in a stimuli-responsive material that combines the properties of the two networks and has the potential to add new properties to the resulting device.

\section{ASSOCIATED CONTENT}

\section{(s) Supporting Information}

The Supporting Information is available free of charge at https://pubs.acs.org/doi/10.1021/acs.macromol.1c00611.

Characterization of the monomer mixture, orthogonality of free-radical and cationic ring-opening polymerization mechanisms, and anisotropic thermomechanical properties of LC-IPN and reproducibility of one-way tripleshape-memory behavior (PDF)

\section{AUTHOR INFORMATION}

\section{Corresponding Author}

Albert P. H. J. Schenning - Laboratory of Stimuli-responsive Functional Materials and Devices, Department of Chemical Engineering and Chemistry, Eindhoven University of Technology, 5612 AE Eindhoven, The Netherlands; Institute for Complex Molecular Systems, Eindhoven University of Technology, 5612 AE Eindhoven, The Netherlands; (ㄱ) orcid.org/0000-0002-3485-1984;

Email: a.p.h.j.schenning@tue.nl

\section{Authors}

Davey C. Hoekstra - Laboratory of Stimuli-responsive Functional Materials and Devices, Department of Chemical Engineering and Chemistry, Eindhoven University of Technology, 5612 AE Eindhoven, The Netherlands; Institute for Complex Molecular Systems, Eindhoven University of Technology, 5612 AE Eindhoven, The Netherlands; (1) orcid.org/0000-0002-4471-588X

Michael G. Debije - Laboratory of Stimuli-responsive Functional Materials and Devices, Department of Chemical Engineering and Chemistry, Eindhoven University of Technology, 5612 AE Eindhoven, The Netherlands; (1) orcid.org/0000-0001-8844-1115

Complete contact information is available at: https://pubs.acs.org/10.1021/acs.macromol.1c00611

\section{Author Contributions}

This manuscript was written through the contributions of all authors. All authors have given approval to the final version of the manuscript.

\section{Funding}

This work was financially supported by the Netherlands Organization for Scientific Research (TOP-PUNT 718.016.003).

\section{Notes}

The authors declare no competing financial interest.

\section{ACKNOWLEDGMENTS}

The authors would like to thank Patricia Visser for initial experiments, Simon Houben for SEM characterization, and Dr. Johan Lub and Dr. Marina Pilz da Cunha for valuable discussion.

\section{REFERENCES}

(1) van Oosten, C. L.; Bastiaansen, C. W. M.; Broer, D. J. Printed Artificial Cilia from Liquid-Crystal Network Actuators Modularly Driven by Light. Nat. Mater. 2009, 8, 677-682.

(2) Ryabchun, A.; Lancia, F.; Nguindjel, A.-D.; Katsonis, N. Humidity-Responsive Actuators from Integrating Liquid Crystal Networks in an Orienting Scaffold. Soft Matter 2017, 13, 8070-8075.

(3) Kularatne, R. S.; Kim, H.; Boothby, J. M.; Ware, T. H. Liquid Crystal Elastomer Actuators: Synthesis, Alignment, and Applications. J. Polym. Sci., Part B: Polym. Phys. 2017, 55, 395-411.

(4) Pilz da Cunha, M.; Peeketi, A. R.; Mehta, K.; Broer, D. J.; Annabattula, R. K.; Schenning, A. P. H. J.; Debije, M. G. A SelfSustained Soft Actuator Able to Rock and Roll. Chem. Commun. 2019, 55, 11029-11032.

(5) Jiang, Z. C.; Xiao, Y. Y.; Tong, X.; Zhao, Y. Selective Decrosslinking in Liquid Crystal Polymer Actuators for Optical Reconfiguration of Origami and Light-Fueled Locomotion. Angew. Chem., Int. Ed. 2019, 58, 5332-5337.

(6) Wu, Y.; Yang, Y.; Qian, X.; Chen, Q.; Wei, Y.; Ji, Y. LiquidCrystalline Soft Actuators with Switchable Thermal Reprogrammability. Angew. Chem., Int. Ed. 2020, 59, 4778-4784.

(7) Zeng, H.; Zhang, H.; Ikkala, O.; Priimagi, A. Associative Learning by Classical Conditioning in Liquid Crystal Network Actuators. Matter 2020, 2, 194-206.

(8) Pilz Da Cunha, M.; Debije, M. G.; Schenning, A. P. H. J. Bioinspired Light-Driven Soft Robots Based on Liquid Crystal Polymers. Chem. Soc. Rev. 2020, 49, 6568-6578.

(9) Liu, D. Surface Dynamics at Photoactive Liquid Crystal Polymer Networks. Adv. Opt. Mater. 2019, 7, No. 1900255.

(10) Warner, M.; Terentjev, E. M. Liquid Crystal Elastomers; International Series of Monographs on Physics; Oxford University Press: Oxford, 2007. 
(11) Ohm, C.; Brehmer, M.; Zentel, R. Liquid Crystalline Elastomers as Actuators and Sensors. Adv. Mater. 2010, 22, 33663387.

(12) White, T. J.; Broer, D. J. Programmable and Adaptive Mechanics with Liquid Crystal Polymer Networks and Elastomers. Nat. Mater. 2015, 14, 1087-1098.

(13) Mol, G. N.; Harris, K. D.; Bastiaansen, C. W. M.; Broer, D. J. Thermo-Mechanical Responses of Liquid-Crystal Networks with a Splayed Molecular Organization. Adv. Funct. Mater. 2005, 15, 11551159.

(14) Sol, J. A. H. P.; Peeketi, A. R.; Vyas, N.; Schenning, A. P. H. J.; Annabattula, R. K.; Debije, M. G. Butterfly Proboscis-Inspired Tight Rolling Tapered Soft Actuators. Chem. Commun. 2019, 55, 17261729.

(15) Lee, K. M.; Koerner, H.; Vaia, R. A.; Bunning, T. J.; White, T. J. Light-Activated Shape Memory of Glassy, Azobenzene Liquid Crystalline Polymer Networks. Soft Matter 2011, 7, 4318-4324.

(16) Lee, K. M.; Bunning, T. J.; White, T. J. Autonomous, HandsFree Shape Memory in Glassy, Liquid Crystalline Polymer Networks. Adv. Mater. 2012, 24, 2839-2843.

(17) Xiao, Y.-Y.; Jiang, Z.-C.; Tong, X.; Zhao, Y. Biomimetic Locomotion of Electrically Powered "Janus" Soft Robots Using a Liquid Crystal Polymer. Adv. Mater. 2019, 31, No. e1903452.

(18) Hoekstra, D. C.; Visser, P. P. M.; Houben, S. J. A.; Lub, J.; Debije, M. G.; Schenning, A. P. H. J. A Foldable Compact Actuator Based on an Oxetane Liquid Crystal Network. J. Appl. Phys. 2021, 129, No. 075101.

(19) Chen, Y.; Chen, C.; Rehman, H. U.; Zheng, X.; Li, H.; Liu, H.; Hedenqvist, M. S. Shape-Memory Polymeric Artificial Muscles: Mechanisms, Applications and Challenges. Molecules 2020, 25, No. 4246.

(20) Scalet, G. Two-Way and Multiple-Way Shape Memory Polymers for Soft Robotics: An Overview. Actuators 2020, 9, 10.

(21) Sperling, L. H. Interpenetrating Polymer Networks and Related Materials; Springer-Verlag US: Boston, 1981.

(22) Silverstein, M. S. Interpenetrating Polymer Networks: So Happy Together? Polymer 2020, 207, No. 122929.

(23) Zhao, Y.; Yuan, G. Interpenetrating Liquid Crystalline Polymer Networks. Macromolecules 1996, 29, 1067-1069.

(24) Zhao, Y.; Yuan, G.; Roche, P. Blends of Side-Chain Liquid Crystalline Polymers: Towards Self-Assembled Interpenetrating Networks. Polymer 1999, 40, 3025-3031.

(25) Ube, T.; Takado, K.; Ikeda, T. Photomobile Properties of Interpenetrating Polymer Network Films Composed of Azobenzene Liquid Crystalline Polymer and Polymethacrylates. Mol. Cryst. Liq. Cryst. 2014, 594, 86-91.

(26) Ube, T.; Takado, K.; Ikeda, T. Photomobile Materials with Interpenetrating Polymer Networks Composed of Liquid-Crystalline and Amorphous Polymers. J. Mater. Chem. C 2015, 3, 8006-8009.

(27) Stumpel, J. E.; Gil, E. R.; Spoelstra, A. B.; Bastiaansen, C. W. M.; Broer, D. J.; Schenning, A. P. H. J. Stimuli-Responsive Materials Based on Interpenetrating Polymer Liquid Crystal Hydrogels. Adv. Funct. Mater. 2015, 25, 3314-3320.

(28) Ube, T.; Minagawa, K.; Ikeda, T. Interpenetrating Polymer Networks of Liquid-Crystalline Azobenzene Polymers and Poly(Dimethylsiloxane) as Photomobile Materials. Soft Matter 2017, 13, 5820-5823.

(29) Kragt, A. J. J.; Broer, D. J.; Schenning, A. P. H. J. Easily Processable and Programmable Responsive Semi-Interpenetrating Liquid Crystalline Polymer Network Coatings with Changing Reflectivities and Surface Topographies. Adv. Funct. Mater. 2018, 28, No. 1704756.

(30) Kragt, A. J. J.; Zuurbier, N. C. M.; Broer, D. J.; Schenning, A. P. H. J. Temperature-Responsive, Multicolor-Changing Photonic Polymers. ACS Appl. Mater. Interfaces 2019, 11, 28172-28179.

(31) Kragt, A. J. J.; Hoekstra, D. C.; Stallinga, S.; Broer, D. J.; Schenning, A. P. H. J. 3D Helix Engineering in Chiral Photonic Materials. Adv. Mater. 2019, 31, No. 1903120.
(32) Deng, Z.; Zhou, G.; De Haan, L. T. Preparation of an Interpenetrating Network of a Poly(Ampholyte) and a Cholesteric Polymer and Investigation of Its Hydrochromic Properties. ACS Appl. Mater. Interfaces 2019, 11, 36044-36051.

(33) Lu, H. F.; Wang, M.; Chen, X. M.; Lin, B. P.; Yang, H. Interpenetrating Liquid-Crystal Polyurethane/Polyacrylate Elastomer with Ultrastrong Mechanical Property. J. Am. Chem. Soc. 2019, 141, 14364-14369.

(34) Hoekstra, D. C.; van der Lubbe, B. P. A. C.; Bus, T.; Yang, L.; Grossiord, N.; Debije, M. G.; Schenning, A. P. H. J. WavelengthSelective Photopolymerization of Hybrid Acrylate-Oxetane Liquid Crystals. Angew. Chem., Int. Ed. 2021, 60, 10935-10941.

(35) Xie, T.; Xiao, X.; Cheng, Y. T. Revealing Triple-Shape Memory Effect by Polymer Bilayers. Macromol. Rapid Commun. 2009, 30, $1823-1827$.

(36) Chatani, S.; Wang, C.; Podgórski, M.; Bowman, C. N. Triple Shape Memory Materials Incorporating Two Distinct Polymer Networks Formed by Selective Thiol-Michael Addition Reactions. Macromolecules 2014, 47, 4949-4954.

(37) Lub, J.; Recaj, V.; Puig, L.; Forcén, P.; Luengo, C. Synthesis, Properties and Photopolymerization of Liquid Crystalline Dioxetanes. Liq. Cryst. 2004, 31, 1627-1637.

(38) van der Zande, B. M. I.; Roosendaal, S. J.; Doornkamp, C.; Steenbakkers, J.; Lub, J. Synthesis, Properties, and Photopolymerization of Liquid-Crystalline Oxetanes: Application in Transflective Liquid-Crystal Displays. Adv. Funct. Mater. 2006, 16, 791-798.

(39) Escuti, M. J.; Cairns, D. R.; Crawford, G. P. Optical-Strain Characteristics of Anisotropic Polymer Films Fabricated from a Liquid Crystal Diacrylate. J. Appl. Phys. 2004, 95, 2386-2390.

(40) Hikmet, R. A. M.; Broer, D. J. Dynamic Mechanical Properties of Anisotropic Networks Formed by Liquid Crystalline Acrylates. Polymer 1991, 32, 1627-1632. 